\title{
"Sepamos, Señores, en que ley vivimos y si emos de tener por nuestra regla al Consejo de Indias": Salamanca in the Philippine Islands
}

\author{
Osvaldo R. Moutin
}

In 1743, Pedro Murillo Velarde sJ, the chair of canon law at the University of Manila in the Philippine Islands, published a handbook of canon law in Madrid, the Cursus Iuris Canonici, Hispani et Indici [...] On the subject of the law of patronage, the title stated that, regarding the patronato real of the New World,

[...] they have the patronage of all the cathedrals in the Indies, and of every other church in the New World and the Philippines. And this patronage of our kings is, in fact, very wide and deep everywhere [...].1

150 years earlier, fray Domingo de Salazar op, first bishop of Manila, would have completely disagreed with this view. The testimonies of the two authors both members of religious orders, both jurists and theologians educated at Salamanca, and both writing from the same place - discussed very similar practices. However, the Jesuit canon lawyer described the juridical institution of patronage and its implications at the moment his handbook was drafted without criticism, whereas the Dominican bishop denounced it as an abusive practice in the Indies. It is Salazar's objection to this institution that will be explored in this chapter.

After training in both branches of law and in theology at Salamanca and spending time as a Dominican missionary in Spanish America, Domingo de Salazar became bishop of Manila on 17 September 1581 . He proved to be a highly contentious figure. He came into conflict with the encomenderos and the

1 “[...] in Indiis habent patronatum omnium Cathedralium, et aliarum quarumcumque Ecclesiarum novi Orbis, et Philippinarum. et hic patronatus est undequaque latissimus et profundissimus siquidem nostrii Reges [...]", Murillo Velarde, Cursus Iuris Canonici, 619. 
governor as soon as he arrived in the archipelago and he also had a turbulent relationship with the Real Audiencia of Manila from almost the first moment it was established in 1583 . This is unsurprising if we consider other centres of the Spanish monarchy. Pedro Moya de Contreras, perhaps the most powerful spiritual minister and royal public servant of the empire at that time - who had accumulated as many offices as was possible -, had a number of problems with other royal authorities. In 1585, Domingo de Salazar was excused from taking part in the Third Provincial Council of Mexico because it was too far to travel to Mexico from the Philippines. He did however send a report to the other bishops so that his opinion could be included in the discussion about patronato real.

This report to the Third Provincial Council of Mexico was not the only time that Domingo de Salazar wrote about the topic: he also discussed it in reports to the king and in some treatises. However, an analysis of this report yields some unique perspectives. The bishop of the Philippines was not addressing the king or the councillors of the Royal Council of Indies but his peers and counterparts, with whom he had a great deal in common and shared similar experiences. They too were bishops in recently founded dioceses where the evangelisation process was still in its early stages, and they similarly found themselves in no shortage of conflicts with the religious orders, the secular clergy, and local authorities. In his personal trajectory, Salazar had a further point in common with many of these other prelates: he, like most of them, had been educated at the University of Salamanca, and had come into contact with the first generation of the so-called "School of Salamanca". They had also been priests for many years to the Spanish and indigenous populations of the New World, and many of them held offices that required significant intellectual preparation. Therefore, the other bishops of the Third Provincial Council of Mexico saw Domingo de Salazar not just as another chorepiscopus, but also as an expert in theology and canon and civil law, and a proven spiritual magistrate of the Indies.

The object of this chapter is to explore the network of those who were educated to be the intellectual elite of the Spanish empire and who played an important role in its expansion. In particular, I will explore the figure of Domingo de Salazar, first bishop of Manila and catalyst of "Salmantine" ideas in their practical dimension, to understand how this network of knowledge and praxis worked. The challenge he formulated to the canonical institution of patronage in his report to the Third Provincial Council of Mexico, as well as in other documents, will be the guiding thread of this inquiry. 
Diego López de Salazar was born into a rich family in Labastida in 1512. At the age of 15 , he went to Salamanca to undertake his studies, which was around the same time that Francisco de Vitoria took his chair in theology at the university. Diego de Salazar graduated as a Bachelor of Canon Law in 1532 and Civil Law in 1539. In November 1545, a year before the death of Francisco de Vitoria, he entered the novitiate of the Dominican Order at the Convent of San Esteban; Bartolomé de Medina and Domingo Báñez were among his fellows there. He changed his name to Domingo, professed on 26 November 1546 - together with Bartolomé de Medina - and immediately embarked on courses in theology, attending the classes of Domingo de Soto and Melchor Cano. In 1552, he was mentioned in the records as a student and a priest. In total, he spent at least 20 years in Salamanca where he may have been a casual (or habitual) witness of the lectures of Francisco de Vitoria and seen the repercussions of the presence of Bartolomé de las Casas, ${ }^{2}$ or of the ideas that circulated during the Valladolid debate. ${ }^{3}$

He arrived in Mexico in 1553 where he taught theology at the Convent of Santo Domingo and worked as a missionary in Oaxaca. In 1558, he joined Pedro de Feria, Domingo de la Anunciación, and three other Dominican friars in the Florida mission, which ended in disaster because of a storm at sea, and he finally returned to Mexico in 1561. Afterwards, he spread the Gospel in Zacatecas. In Mexico, - never one to shy away from conflict - he was involved in the controversy about the Bula de la Cruzada, which the Dominicans were opposed to, and also had a confrontation with the archbishop about the privileges of the religious orders. During these years, he started to write a now lost treatise on the titles of possession of the Spanish Crown to the Indies. Alonso de Zorita wrote that he had seen a draft version of it and that its arguments amounted to a continuation of those of

2 In 1583, when he was already bishop of Manila, he wrote to the king that "Ya V. Magd. save con quanto escrupolo se tratan estos negocios de indias condenando casi todos los letrados de España y aun los de la Indias las conquistas que contra indios se hecho ... deste parecer fuy yo en algun tiempo porque me crie con la doctrina del Obispo de Chiapa y deste parecer fuy en mas de veinte y tres años que estuve en la Nueva España [...]”, “Carta de Domingo de Salazar OP a Felipe II sobre la necesidad de entrar a China con brazo armado, dada la oposición de las autoridades chinas a la entrada de misioneros cristianos", in Colín and Pastells, Labor evangélica, 312 .

3 Biographical information is taken from Gutiérrez, "Domingo de Salazar, op, Primer Obispo de Filipinas, 1512-1594". 
Francisco de Vitoria. ${ }^{4}$ In 1571, he was appointed calificador of the Inquisition, which had been recently established in Mexico, and soon found himself in the middle of a quarrel between the archbishop and the viceroy. The dispute had been started by a work of Alonso de Molina in which he introduced the viceroy as the "supremo y cabeza de esta Iglesia de Nueva España". In 1575, Salazar travelled to Spain as procurator of his order to represent its interests to Philip II. His preaching at court, which urged that restitution should be made to the indigenous populations of the New World, earned him a short term in jail for his efforts. He returned to the Convent of San Esteban in Salamanca where, in 1578, he was appointed first bishop of Manila. In 1579, he embarked for the Philippine Islands, passing through Mexico, and eventually arrived at his see on 17 September $1581 .^{5}$

As a suffragan of the archdiocese of Mexico, he was invited to take part in the Third Provincial Council of Mexico that was due to start in January 1585. He excused himself from attending in person on account of the distance of Mexico from his see and accepted instead the archbishop's invitation to send in writing "el aviso de las cosas que acá tienen necesidad de remedio, para que allá se ponga el que más convenga”. ${ }^{6} \mathrm{He}$ penned this report in June 1584 , and it was sent to be read out at the council.

4 "Fray Francisco de Victoria, de la Orden de los Predicadores, doctissimo varón y de muy gran religión y vida muy aprouada, catredatico de Prima de Teología en Salamanca, que fue vno de los mejores theologos que uvo en su tiempo, y de muy claro juizio y muy solida doctrina, escriuió entre otras cosas dos reletiones: la vna yntituló De Indis insulanis, y la otra De jure belli donde trata de la conquista, doctrina y conuersion de las Yndias y naturales delJas; y fray Domingo de Salazar, de la misma Orden, discípulo suyo y que a estado muchos años en la Nueua España y en otras partes de Yndias, entendiendo en la conuersion y doctrina de los naturales dellas con muy gran zelo, diligencia y cuydado, porque es muy buen religioso y muy exemplar en toda virtud y christiandad, y muy aprouado predicador y de muy docta y solida doctrina, y ahora es obispo de las yslas del Ponyente o Philipinas; a escrito en latín vn tratado que yntituló: De modo quo Rex Hispaniarum et sui locum tenentes habere teneantur in regimine Indiarum, y lo comengo á escriuir leyendo Theologia en la Unyversidad de México; sigue en el yntento que su doctissimo maestro tuvo en sus Reletiones y el obispo de Chiapa en lo que escriuió; y estando yo en Madrid el año de 1572 donde el auía venido de México a negocios de su Orden, me lo prestó para que lo viese; muestra en el su grande abilidad y muchas letras y su mui delicado y claro juyzio y agudo yngenio y su muy rica y felice memoria, donde trata los negocios de Yndias muy de raiz, como quien los los vio y los entendió con muy particular cuydado, y algunas cosas de las que su maestro y el obispo an dicho las estiende y declara, y en otras las contradize con muy firmes y fuertes autoridades y delicadas razones, y si lo acaba sería una cosa mui digna de ser leyda y muy estimada", in Zorita, Historia de la Nueva España, 13-14.

5 Unless indicated otherwise, all biographical data is taken from Gutiérrez, "Domingo de Salazar, OP, Primer Obispo de Filipinas (1512-1594)".

6 Burrus, "Salazar's Report to the Third Mexican Council", 70. 


\section{Salazar's Report to the Third Provincial Council of Mexico and Other Reports by the Same Author}

The titles that justified the Spanish conquest and occupation of the Indies were debated on several occasions during the 16th century. The most famous of these debates is that between Bartolomé de las Casas and Juan Ginés de Sepúlveda in Valladolid, but the subsequent theological and juridical reflexion on the matter at the University of Salamanca - starting with Francisco de Vitoria, and continued for a century by his disciples - was also highly influential in shaping ideas about how the overseas empire was to be governed. It is not necessary to explore the different titles of justification in detail here, but for the purpose of this chapter it will suffice to say that Salazar made use of some of the conclusions reached in these debates to formulate the ideas about patronato real that he expressed in his report to the council. Before examining his opinion, it is important to emphasise that even though the Spanish Crown could justify some of the titles of conquest and possession over the Indies, it did not necessarily mean that they were the patrons of the church.

Patronage was a highly developed juridical institute which was firmly consolidated in classical canon law and frequently practised in the Iberian Peninsula. By virtue of this institute, those who founded, endowed (dotar), or built a church could receive the favour of the ecclesiastical authorities to present the clergy for offices in that church. ${ }^{7}$ The person who carried out this activity was called the "patron". ${ }^{8}$ According to canonical doctrine, it was considered a grace that was also available to laymen. ${ }^{9}$ The impression given by legislation and treatises about patronage is that it was a very irenic institute for very specific circumstances: it was enacted to assist the propagation of the Roman Catholic faith in missionary lands that were mainly inhabited by nonChristian populations or heretics. In such territories, it was thought to be more appropriate for the right of presentation to be given to the secular authority, which contributed to the development of the church since they were in a better position to know who best to appoint. However, in the early modern period, an institute that might have been very expedient in a small territory was then applied to a whole, previously-unknown continent, and more. To suppose that there was only one fixed conceptualisation of royal patronage that lasted for the entire colonial period would be a gross misunderstanding. The report of Domingo de Salazar gives us the opportunity to examine an opinion which

7 C. 16 , q. 7.c. 32.

8 C. 12 , q. 12 , c. 61 .

9 C. 16, q. 7. c. 32. Gloss Fundadores. 
would later be considered contrary to the general orthodoxy elaborated by Murillo Velarde a century and a half later, but which was nonetheless written by one of the most important and erudite church authorities of the Spanish empire of the late 16 th century.

This report differed from other reports by the same author: those written to the king ${ }^{10}$ or to the Council of Indies were energetic, ${ }^{11}$ and they reveal a man who had no doubt about the best way to proceed. ${ }^{2}$ Those arguments were based on auctoritas ${ }^{13}$ and his message was not advisory but denunciatory. ${ }^{14}$

10 Salazar clearly questioned royal patronage, writing boldly in 1582: "Quanto al cumplimiento de lo que por la carta se me manda, ya consta a su majestad que soy el primer obispo de estas islas, y que por virtud de las letras apóstolicas que para la erección de esta iglesia se expidieron, y porque así vuestra majestad lo pidió al sumo pontífice al tiempo que se le trató de la erección de la catedral de estas islas, yo tengo derecho para instituir la primera vez todas las prebendas de la catedral y beneficios de todo el obispado y nombrar personas que las sirvan; y después de una vez nombradas, en vacando la presentación de ellas, por virtud de las dichas letras apostólicas, pertenece a vuestra majestad y sus sucesores [...]", in Gutiérrez, "Letter of Domingo de Salazar, op, First Bishop of the Philippines to King Phillip II (1582)", 298.

11 By way of example, "Para que claramente se vea que aquella primera entrada que los españoles hicieron en las Filipinas no se puede decir que los naturales (que) entonces se hallaron presentes hubiesen tomado por su señor al rey de Castilla, hanse de ver las obras y tratamientos que recibieron de los españoles, para que se diga o presuma que voluntariamente se inclinaron a recibir por rey al que lo era de hombres que tan malos tratamientos los hacían", in Salazar, "Tratado [...] acerca de llevar tributos a los infieles de las Islas Filipinas", 130.

12 "Primera conclusión. No puede el rey nuestro señor fundar el derecho de hechar ni llevar tributos a los ynfieles naturales de las Filipinas en el primer título de los dos contenido en el tercer fundamento, que es por razón del gobierno temporal", in Salazar, "Tratado [...] acerca de llevar tributos a los infieles de las Islas Filipinas", 128.

13 For example, "Pero Nuestro Señor, como queda dicho en el tercero fundamento, lo hizo mejor de no darle dominio sobre que hubiese de andar en guerras; y pues el rey de Castilla no tiene sobre las Yndias otro título más del que por razón de la fe le pertenece, como arriba queda dicho, síguese que antes de haberla recibido los ynfieles no les pueden hechar tributos ni compelerlos a que los paguen, y esto es lo que dijo muy bien Don Fr. Bartolomé de las Casas, Obispo de Chiapa, en el libro intitulado "Tratado Comprovatorio", donde dice que los reyes de Castilla no tienen cumplida jurisdicción sobre los ynfieles de las Yndias hasta que haian recibido la fe, que es conforme a la doctrina de Santo Thomás en el libro IV de las "Sentencias" y lo mismo aquí decimos.", in Salazar, "Tratado [...] acerca de llevar tributos a los infieles de las Islas Filipinas", 149.

14 "Tercer punto. Los tributos que hasta aquí se han llevado de encomiendas cuyos vecinos son infieles ha sido contra justicia, con obligación de restituirlos y con la misma obligación quedarán los que de aquí en adelante los llevaren, si primero no se ponen en todas ellas ministros del Evangelio que traten de que los infieles voluntariamente, sin fuerza que se les haga ni temor que ese les ponga, reciban la fe y se hagan del gremio de Iglesia y 
When he addressed his peers, however, his manner was more direct, though still formal, ${ }^{15}$ in its expression of his insecurities ${ }^{16}$ and not infrequent admissions of murmuring (i. e. grumbling). ${ }^{17}$

Salazar's "Report to the Third Mexican Council" also differed from other documents sent to the royal authorities in its comparatively few references to other authorities: the first was to the "maestro Vitoria" and his Relectio de potestate ecclesiae with no further details, ${ }^{18}$ the second was a generic reference to Thomas Aquinas, ${ }^{19}$ the third was a brief mention of the martyrdom of St. Augustine of Canterbury, ${ }^{20}$ and the others were references to the royal legislation of the Indies, which he introduced vaguely with expressions like "la cédula entre las impresas"

In order to ground his knowledge about abuses involving patronato real, Salazar made use of various historical cases in the recent past of the Church in the Indies. For example, he reminded the bishops that he had taken part in the Second Provincial Council of Mexico (1565);21 he wrote about when the

sólo éste y ningún otro título ni derecho hay para poder llevar tributos de aquellas islas", in Salazar, "Tratado [...] acerca de llevar tributos a los infieles de las Islas Filipinas", 192.

15 "Quanta alegría y consuelo reciví de la convocación quel illustrísimo Arçobispo a hecho para celebrar ese santo Concilio por ser cosa de mí muy deseada de muchos años atrás, con tanto dolor y tristeça quedo por no poderme hallar en él. Porque ninguno de los señores obispos que a él an de venir, tenían tanta necesidad de hallarse en él como yo, [...]", in Burrus, "Salazar's Report to the Third Mexican Council", 69.

16 "Pues, para consuelo mío y declaración de muchas dudas, dificultades y escrúpulos que tengo, el mayor remedio que yo tenía era hallarme en esa sancta congregación y dar qüenta a vuestras señorías de todas las cosas que en este obispado me tienen afligido [...]", in Burrus, "Salazar's Report to the Third Mexican Council", 70.

"[...] y algunas veces murmuraba de los señores obispos pasasen de ellas", in Burrus, "Salazar's Report to the Third Mexican Council", 71; “[...] con arto dolor mío que lo vi y lo murmuré [...]", in Burrus, "Salazar's Report to the Third Mexican Council", 77. On the gravity of the moral implications of "murmuring", see Azpilcueta, Manual de Confessores, chapter XVIII, "Del viII Mandamiento", numbers 16-50.

18 Burrus, "Salazar's Report to the Third Mexican Council", 76. In footnote 29, Burrus wrote that the argument is actually found in Prima Relectio de Indis noviter inventis, section 2, number 5 , not in the relectio referred to.

19 Opus contra impugnates religionem.

$20 \quad$ ¿Qué más razón tuvo Santo Tomás Canturiense para dexarse matar por lo qual murió, que tenemos nosotros para morir por muchas cosas que contra nosotros se hacen?", in Burrus, "Salazar's Report to the Third Mexican Council", 78.

21 “[...] y en un concilio que el postrero que en esa ciudad se celebró, en tiempo del señor arçobispo don fray Alonso de Montúfar (que en gloria sea), lo traté con algunos de los señores obispos que en él se hallaron y todos me dezían que tenía razón [...]", in Burrus, "Salazar's Report to the Third Mexican Council", 71. 
oidores had refused to allow the use of the palio ${ }^{22}$ to welcome the new bishops that were about to take possession of their sees in Guatemala, Puebla, and Mexico during the procession of Corpus Christi ${ }^{23}$ he recalled the presence of the viceroy during the celebration of the Third Provincial Council of Lima $(1582 / 1583) ; 24$ and he recounted an episode he had witnessed in the Iberian Peninsula. ${ }^{25}$

Nevertheless, the report maintained a certain official tone in so far as it was a response to the request of the archbishop at the meeting of a provincial council and was to be read to the prelates. ${ }^{26}$ However, the language of the bishop of Manila was direct, honest, and sometimes even rude, ${ }^{27}$ the simple explanation for which is that he knew most of his interlocutors, many of whom had been his companions at Salamanca or in the New World. ${ }^{28}$

\section{The Third Provincial Council of Mexico: A Community of Ideas and Values}

Salazar was well connected to most of the prelates at the council, many of whom had studied at Salamanca. It has been said that Pedro Moya de Contreras, archbishop of Mexico, earned his doctorate in canon law at Salamanca, and the records show that he was certainly at the university between 1551 and $15544^{29}$ When he founded the Inquisition in Mexico in 1571, he appointed Salazar as censor. Fray Pedro de Feria, who was a missionary in Oaxaca and Salazar's superior in the failed mission to Florida, pursued his religious profession in

22 He did not refer to the pallium that the Roman pontiff gives to the archbishops but to the dosel or fabric that covered the Holy Sacrament during processions. See the word palio in Covarrubias, Tesoro de la lengua castellana o española, 574v.

23 Burrus, "Salazar's Report to the Third Mexican Council", 77.

24 Burrus, "Salazar's Report to the Third Mexican Council", 78.

25 "Y soi testigo de vista que en El Escorial, diciendo la missa el prior, presente su Magestad, en la oración nombró primero al perlado que al Rey [...]", in Burrus, "Salazar's Report to the Third Mexican Council", 77 .

26 Burrus, "Salazar's Report to the Third Mexican Council", 70.

27 "Yo, Señores reverendísimos, no me quiero mostrar más zeloso que todos los demás, ni quiero meter la mano en más de lo que devo: pero por reverencia de Dios y por lo que deven al cargo en que Dios los tiene puestos, suplico humildemente a vuestras Señorías que, si estas son cosas por que no debemos pasar, que no se nos ponga por delante los trabaxos que emos de pasar en contradezirlo [...]", in Burrus, "Salazar's Report to the Third Mexican Council", 74 .

28 Lorenzana, Concilios Provinciales, 214.

29 Poole, Pedro Moya de Contreras, 31. 
the Order of Preachers in 1545 and studied arts between 1546 and 1547. He then returned to Salamanca to study theology between 1571 and 1573, when he was presented to the see of Chiapas by the king.

Bartolomé de Ledesma, another Dominican, had also professed at the Convent of San Esteban in 1543 and studied arts and theology in Salamanca between 1546 and 1547. In 1551, Archbishop Montúfar chose Ledesma to accompany him to New Spain. In 1566, he published the first edition of the Summa de Sacramentos, which was reprinted in 1585 . He taught theology in the Dominican convents and at the University of Mexico, and he was also a consultant at the Third Provincial Council of Lima (1582-1583). In his report, Salazar referred to him as "Señor electo de Panamá", although he was already bishop of Antequera by the time of the council, and named him as the interlocutor to whom he addressed his complaints because both of them had been at the Second Provincial Council of Mexico (1585). ${ }^{30}$

Antonio de Hervías, bishop of Verapaz, had also professed at the Convent of San Esteban in Salamanca in 1550. He held the chair of theology at Lima before being appointed bishop of Verapaz. Fray Domingo de Alzola, bishop of Nueva Galicia, was a Dominican friar from the convent of Valladolid. In 1581, still acting as visitor of his order in Mexico, he had been unwilling to give licence to Salazar to take the most experienced friars with him to the Philippines, although he did help him to get others from Spain. ${ }^{31}$ Diego Romano, bishop of Puebla, seems to have studied law at Salamanca. ${ }^{32}$ In short, Domingo de Salazar may be said to have had personal knowledge of many of the prelates owing to their shared conventual life and at least some coincidences in their academic careers. ${ }^{33}$

However, it was not just personal acquaintance or friendship that allowed him to get his message across more easily. Domingo de Salazar's natural and

30 "Y si el Señor electo de Panamá se hallare en esa sancta congregación, su Señoría será buen testigo de las veces que con él traté esto y quán mal le parecería que los señores obispos no tratasen del remedio de cosas que tanto lo avían menester, o a lo menos supiesen de su Santidad si era servido que pasasen por ellas" in Burrus, "Salazar's Report to the Third Mexican Council", 71 .

31 Only one of the Dominican friars who travelled from Spain to the Philippines arrived: the rest died or took another path. See González Pola, "Fundación de la Provincia de Nuestra Señora del Rosario", 125-131, and González Pola, "Aportación de la Provincia de Santiago de México", 99. On the difficulties that Salazar faced when requesting Dominican friars for the Philippines, see Pita Moreda, Los predicadores novohispanos del siglo XVI.

32 Díaz de la Guardia y López, "Granada y el derecho en el Concilio Tercero Mexicano $(1585) ", 157$.

33 Biographical data from Carrillo Cázares, Manuscritos del Concilio Tercero Provincial Mexicano (1585), vol. 1, XXIX-XXXVII. 
self-assured report demonstrates that there was a community of ideas and values. The bishop of Manila did not need to argue with extensive references to canons, theology, or jurisprudence because his ideas were familiar to his audience, who shared them with him. Their common personal trajectories entailed the convergence of their intellectual trajectories. ${ }^{34}$

As well as through the formal education received at the University of Salamanca, there were other opportunities for ideas and people to interact. When the emperor wrote to the prior of the Convent of San Esteban in Salamanca to prohibit the friars from discussing the titles of the conquest of America, he claimed that it had reached his ears that "han puesto en platica y tratado en sermones y en repeticiones". ${ }^{35}$ The pulpit is, first and foremost, a designated place for the transmission of knowledge, but it is also worth considering the existence of other spaces outside the university and closer to the conventual life of trainee priests, missionaries, theologians, and jurists that provided an arena for sharing ideas and knowledge, such as readings in the refectory, participation in the divine offices, and the spiritual direction of the novices.

Royal Patronage in Salazar's Report to the Third Provincial Council of Mexico

The report that Salazar sent to the council was divided into 24 sections and also contained an introduction, a conclusion, and a notarial certificate. The purpose of the text was to ask for advice about how to proceed in various situations which, according to the author, were "contra la dignidad i preminencia de la Yglesia i contra su libertad". ${ }^{36}$ In the following pages, I will analyse the report thematically but I shall first summarise the sections where he interrogated the exercise of episcopal authority and expressed his doubts about how this was happening in the Indies: 1) how the royal authorities interfered in ecclesiastical matters, even those sanctioned by the bull In Coena Domini; 2) the royal cédula that prevented bishops from appointing a prosecutor outside the episcopal see; 3) another cédula preventing the promulgation of the provincial councils of the Indies unless they were approved by the Council of the Indies; 4) the need

34 The thoughts of the Mexican bishops were close to those of Las Casas at least once in the proceedings, Poole, "Successors to Las Casas" and Poole, Pedro Moya de Contreras, 282.

35 Fernández Rodríguez, Los dominicos en el contexto de la primera evangelización de México, 40-41.

36 Burrus, "Salazar's Report to the Third Mexican Council”, 71. 
for the pase regio for whatever the pope commanded for the Indies; 5) that it was enough for the religious orders to ask the royal authorities to erect a convent even if they did not have the episcopal licence that was required by the Council of Trent; 6) that bishops could not impose pecuniary sanctions; 7) and 9) that royal authorities took precedence over ecclesiastical prelates, even at liturgical celebrations; 8) that royal authorities prevented the faithful from going out to receive the bishop when he made his first entrance to take possession of his diocese; 10) that the king's delegate had to be present and sat next to the archbishop at provincial councils; 11 ) that the cédula of patronato real had been introduced and that Archbishop Moya de Contreras had accepted it without the consent of his suffragans, and also that those bishops had not resisted it; 12$)$ that the bishop's authority was negligible compared with that of the councillors of the Council of the Indies; 13) what value and meaning the bishops' oath to obey the ecclesiastical canons had in light of the actual contemporary circumstances; 14 ) by what right lay tribunals judged "miserable persons", who were, by derecho común, under the law of the Church; 15) the difficulties the bishops had in governing the Indians, "el fin principal porque a esta tierra venimos" 37 ; 16) why the salidas to convert Indians were carried out without priests and without informing the bishop; 17) why ecclesiastics had to ask for help from the royal justice to arrest Indians; 18) why the secular authorities had to intervene in matters relating to the conversion of Indians; 19) why a royal charter dealt with the fight against the idolatries of the Indians, a matter that properly pertained to bishops; 20 ) the obligation of observance of the encomenderos; 21) the opposition of the religious orders to obeying episcopal authority; 22), 23) and 24) the conversion and cura animarum of the Indians.

The ecclesiology of Domingo de Salazar was clearly Tridentine, "la república eclesiástica (es) perfecta e independiente", ${ }^{38}$ and so he was particularly concerned about the how the patronato real impacted on the oath that the bishops had to swear about observing the canons. ${ }^{39}$ Therefore, he challenged the bishops to define who their lord was.

37 Burrus, "Salazar's Report to the Third Mexican Council", 79.

38 Burrus, "Salazar's Report to the Third Mexican Council", 74.

39 Burrus, "Salazar's Report to the Third Mexican Council", 74. In another report, he wrote, "si el juramento se entiende según suena, vivimos los obispos en mucho peligro", referring to the danger to souls that was introduced by this situation. In another report, he complained about the way in which his missionary campaign was presented to the natives by the Spanish secular authorities, "[...] cuando yo entré en esta tierra, como se divulgó entre ellos (los indios) mi venida, y se dijo que yo era el capitán de los clérigos, como el gobernador lo es de los legos, preguntaron si venía yo a echarles algún tributo, como cosa que ellos tanto temen", Gutiérrez, "Domingo de Salazar's Report", 296. 
Sepamos, Señores, en que ley vivimos y si emos de tener por nuestra regla al Consejo de Indias; y si así es, pasemos muy en buenora por quanto nos mandare; pero, si no a de ser nuestra regla, sino la Yglesia Romana, declárenos ella que en esto emos de hazer. Si no lo tiene declarado; y pasemos por lo que emos de pasar, y resistamos a lo quemos de resistir, y no vivamos a ciegas; porque aquí se puedan introducir mil inconvenientes que después no se puedan remediar. ${ }^{40}$

In his opinion, the bishops were afraid of the royal authorities and their conduct in the Indies and did not have the courage to oppose them, and therefore "la potencia secular se va metiendo en las cosas eclesiásticas [...] especialmente los virreyes y gobernadores, y mucho más las audiencias". ${ }^{41}$ The consequence of this was that the bishops, who depended on royal authority, had become susceptible to excommunication under the bull In Coena Domini. All the cases he described were rooted in the abusive use of the right of patronage, and although on some occasions he suggested turning to the Roman pontiff or to the king for guidance, there is no doubt that he believed that it was the duty of the bishops to defend themselves or to take the initiative when responding to events. He saw the provincial council as the opportunity to do so, "Y acuérdense vuestras Señorías que ese concilio se celebra en las Indias y que a de ser para remedio de las cosas della [...]". ${ }^{42}$

Domingo de Salazar was energetic in establishing locality as the central idea of the council and its usefulness. ${ }^{43}$ The prelates of the Indies, who had studied, taught, preached, administered the sacraments, and governed the Indian dioceses were the only ones who truly knew the reality confronting them and could accordingly find the right response,

[...] que pues la autoridad de cada obispo es tanta que, por el derecho de la Yglesia, se puede oponer contra la potencia de cualquier príncipe que lo quiera usurpar, mucha mayor es la de todos juntos congregados en concilio que, aunque sea provincial, sabemos de quánta authoridad a sido en la Yglesia de Dios. ${ }^{44}$

\footnotetext{
40 Burrus, "Salazar's Report to the Third Mexican Council", 74-75.

41 Burrus, "Salazar's Report to the Third Mexican Council", 72.

42 Burrus, "Salazar's Report to the Third Mexican Council", 8o.

43 Moutin, Legislar en la América hispánica en la temprana edad moderna, 150-154.

44 Burrus, "Salazar's Report to the Third Mexican Council", 72.
} 
Episcopal authority derived from God was sufficient to govern and to parry the advances of secular power, whether exercised individually or, even more so, when exercised as a group in a provincial council. The case was different with the officials in the orbit of the king in Spain.

Y atrévome a decir esto porque, aunque Vuestra Magestad tiene tan cerca de si tantos y tan excelentes letrados en todas las facultades, pero para determinar muchas cosas de Indias, sin duda es menester haber estado en ellas, y no pocos años. ${ }^{45}$

Their first-hand knowledge of the land was what qualified the bishops to the detriment of the councillors of the Royal Council of the Indies,

Maravillosa cosa que diez obispos que se juntan con su arçobispo para tratar del remedio de sus ovejas tengan tan poca authoridad con su Magestad que no quiera que tenga fuerça ni se pueda publicar lo que determinaren, hasta que pase por mano de quatro Oydores que tienen en Consejo de Indias, que no suelen ser más letrados ni más santos que los obispos que lo an celebrado. ${ }^{46}$

From a practical point of view, royal officials in Spain were unaware of the reality of the Indies. ${ }^{47}$ Not only did the bishops have the same academic qualifications as the councillors, they also had the requisite authority and experience of the reality of the Indies. Moreover, it was the bishops, rather than the royal officials on the ground, who were the true agents of the conversion of

45 Gutiérrez, "Domingo de Salazar's Report", 292.

46 Burrus, "Salazar's Report to the Third Mexican Council", 74.

47 In another report to the king, he clearly described the negative consequences of this, “[... es necesario que tenga clara y muy cumplida noticia del hecho [...], si no tiene bastante noticia del hecho para fundar el derecho, está obligado a todos los daños que las partes recibieren por su causa, lo qual es nuestro caso, y tanto más, quanto con maior dificultad se puede saber el hecho, que lo es lo principal que en nuestra materia se requiere para poder hablar sin peligro de la conciencia, y por el gran peligro que hay en determinar lo que se ha de tener, porque el derecho más claro está que el sol. La dificultad está en que la noticia del hecho ha de venir de tan lejos como están las Filipinas de España, donde se verifica el refrán 'de luengas vías, grandes mentiras', de manera que el que no ha estado allá ha de andar con grandíssimo recato para no ser engañado, porque en las cosas que tocan a los indios muy poquitos son los que hablan sin pretender algún interés propio o de sus amigos y aliados", in Salazar, "Tratado [...] acerca de llevar tributos a los infieles de las Islas Filipinas", 127. 
the indigenous peoples, which was the ultimate reason and cornerstone of the Spanish presence in the New World.

Y pues emos venido a tratar desto, paréceme que no sería malo tratar con su Magestad y aun con su Santidad la gran crudeldad de que se usa con las Yglesias de las Indias y obispos y prevendados de ellas los españoles con solo título de la conversión de los naturales, cuio propísimo officio y cuidado pertenece a los obispos $[\ldots] .^{48}$

It is worth noting that Domingo de Salazar was not asking for new rules but sought instead to more closely define and establish what ought to happen in accordance with the law, ${ }^{49}$ or at least to be allowed to ask the opinion of the king or the pope. Domingo de Salazar had one fear which, as we shall see, was not unfounded.

[...] porque muchas cosas hacen los príncipes y gobernadores de las repúblicas contra el derecho de la Yglesia por no aver quien se lo contradiga. Y sin duda que muchas destas cosas no tienen más dificultad de la que nosotros ymaginamos; que si nos pusiésemos a ello, saldríamos con muchas coasa que por dexarlas así ban tomando fuerças y después tendrán fuerça de costumbre usada y no abrá quien pueda quitarlas. ${ }^{50}$

The law of patronage, as it was practiced, was expanding, restricting the freedom of the Church as it did so. Domingo de Salazar feared that these abuses might come to be considered customary in the future, and he was right to be afraid. ${ }^{51}$ In his report, he enumerated different areas of action - sometimes generically, sometimes offering specific instances - in which the freedom of

48 Burrus, "Salazar's Report to the Third Mexican Council", 81.

49 " [...] porque donde tales personas se an de juntar para lo ques de derecho, no tienen necesidad de quien les dé aviso [...]", in Burrus, "Salazar's Report to the Third Mexican Council", 70 .

$5^{\circ} \quad$ Burrus, "Salazar's Report to the Third Mexican Council", 74.

$5^{1}$ For example, what Pedro Murillo Velarde singled out as ordinary practice was an abuse in the eyes of Salazar 15 o years earlier, "In his Indiarum Provinciis nulla Bulla, vel Breve Apostolicum, etiam pro indulgentiis lucrandis concesum, potest publicari, nisi prius sit in Supremo Indiarum Consilio praesentatum, ut ibidem examinatur, an opponantur Regio patronatui, vel aliis nostrorum Regium privilegiis", Murillo Velarde, Cursus Iuris Canonici, 34 . 
the Church and its mission were being violated or restricted by abusive practices related to the law of patronage.

Domingo de Salazar's report was received on 23 February 1585 . Ten days later, it was read and recorded in the meeting room of the council. ${ }^{52} 11$ points were explicitly made note of. Many of its requests were incorporated into a letter, which was accompanied by three reports, that the provincial council sent to the king. ${ }^{53}$ It is also possible to see its direct influence on some of the decrees that were issued by the council. Compare, for example, the sixteenth point of the report with a decree of the Third Mexican Provincial Council (book 5, title 8 , "De injuriis et damno dato"):

\section{Report of Salazar}

Las entradas que se avían de hazer para convertir los indios y que vieniesen en conocimiento de Dios, los gobernadores los hacen sin dar más qüenta dellas a los obispos que si estuviesen aquí por espantajos y quando mucho después que ya lo tienen todo concertado, le piden al obispo un clérigo que baya con los soldados; y, aunque no lo aya para dárselo, no por eso dejan de hazer su jornada, porque su intento no es yr a convertir sino a conquistar $[\ldots] .{ }^{54}$

\section{Decree of the council}

Para que no aya tanto desorden que las injurias nascan de aquellos cuyo offiçio es amparar y defender a los ynoçentes y miserables, y la experiencia ha manisfestado que de las conquistas y entradas en tierra de infieles se siguen gravísimos daños e irreparables, este sancto conçilio ordena y manda que ningún clérigo acompañe a los soldados en las tales entradas sin licencia expresa del prelado, so pena de excomunión mayor latae sententiae y que será castigado con otras penas a arbitrio del ordinario, y lo mismo encarga a los rreligiosos guarden y cumplan, pues saben la importançia dello. ${ }^{55}$

\footnotetext{
52 Carrillo Cázares, Manuscritos del Concilio Tercero Provincial Mexicano (1585), vol. 1, 699-700.

53 Carrillo Cázares, Manuscritos del Concilio Tercero Provincial Mexicano (1585), vol. 2, 69108; another copy on 112-155.

54 Burrus, "Salazar's Report to the Third Mexican Council", 74.

55 Martínez Ferrer, Decretos del Concilio Tercero Provincial Mexicano 1585, 602.
} 


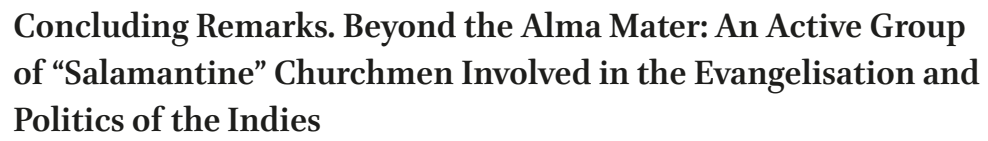

The report of Domingo de Salazar was not the only one presented to the Third Provincial Council of Mexico. If the Salamanca School was a "think tank" in the Iberian Peninsula, those who were ideologically close to its way of thinking were undoubtedly very inclined to action. It is difficult to know people's heartfelt opinions - particularly people of the past - and the reasons for their decisions, and so the only recourse for the historian is to try to reconstruct the facts on the basis of contemporary documentation. Domingo de Salazar understood that it was the pastoral duty of the bishops to promulgate the decrees of the provincial council without waiting for the approval of the Council of the Indies, contrary to what was stipulated by royal decree,

Otra cédula ay en que manda que ningún concilio probincial se pueda promulgar en Indias hasta llevarlo al Consejo dellas para en él se vea lo que se a de publicar. Si esto es razón de salir o no, vuestras Señorías lo verán; que yo bien sé que, por mucho que se desvelen en mirar por lo que conviene a sus ovejas, no a de salir más a luz que salió otro que se embió allá que creo nunca a parecido. ${ }^{56}$

This recommendation did not pass unnoticed by the bishops assembled at the Third Provincial Council of Mexico as the conciliar secretary noted in his records " $4{ }^{\circ}$ Adviértase la cédula en lo que toca a no imprimir el concilio o publicar sin que primero se vea por el Consejo". 57

By early September 1585, all the conciliar documents were completed and the only thing that remained before the provincial council could be concluded was the signing of the decrees by the bishops. On 7 September, Fray Gómez de Córdoba, bishop of Guatemala, demanded of Archbishop Pedro Moya de Contreras - on behalf of all the suffragan bishops - that the provincial council be promulgated by the end of September, without prior remission to the Royal Council of the Indies. The bishops met again several times but the archbishop, as the king's representative and presently viceroy of New Spain, insisted that the decrees should be sent to the Council of the Indies before publication. At successive meetings, the suffragan bishops threatened

$5^{6}$ Burrus, "Salazar's Report to the Third Mexican Council", 73-74.

57 Carrillo Cázares, Manuscritos del Concilio Tercero Provincial Mexicano (1585), vol. 1, 699. 
to return to their sees without signing them if they were not promulgated immediately. The bishops resisted the real cédula by affirming that its remit extended to diocesan synods but not provincial councils. ${ }^{58}$ Finally, the archbishop agreed to a semi-public promulgation. Pedro Moya de Contreras's attitude might suggest that he was the only royalist among the bishops, but, at the end of the 18th century, one reader of these documents doubted the archbishop's conviction.

Nota. Si la repugnancia, oposición y protestas del Señor Arzobispo a la publicación del Concilio fueron verdaderas o precisamente políticas, con respecto a su empleo de Virrey, puede inferirse del texido todo de este punto, y un de todo el concilio, constante en estos tres tomos. ${ }^{59}$

Although the story of the promulgation, printing, and application of the Third Provincial Council of Mexico does not end here, ${ }^{60}$ I like to think that Domingo de Salazar was not only unsurprised by the behaviour of his fellow bishops, but that it even put a smile on his face. ${ }^{61}$

It is difficult to objectively detect the presence of Salamancan ideas in the Indies if there is no consensus about what the School of Salamanca was. Considered as an intellectual, as well as a teacher, defender of the Indians, evangeliser, and politician, Domingo de Salazar fulfils sufficient requirements to be considered as a representative of the School of Salamanca, and therefore helps us expand and define what this means precisely. Further research into the biographical and intellectual profiles of those involved in the evangelisation and politics of the Indies may help us discover a theoretical framework that goes beyond any simple link to the alma mater of Salamanca.

58 Recopilación de la Leyes de los Reynos de Las Indias, book 1, title 8, law 6, "Que los concilios provinciales celebrados en Indias se envíen al consejo antes de su impresión y publicación y los sinodales baste que los vean los virreyes, presidentes y oidores del distrito".

59 Carrillo Cázares, Manuscritos del Concilio Tercero Provincial Mexicano (1585), vol. 2, 32. On Pedro Moya de Contreras's royalism, see Semboloni, "El Tercer Concilio Provincial Mexicano y el Virrey".

6o Carrillo Cázares, Manuscritos del Concilio Tercero Provincial Mexicano (1585), vol. 3, 445539; Poole, "Opposition to the Third Mexican Council"; Poole, Pedro Moya de Contreras, 291-307.

61 For an anti-royalist interpretation of the bishops' attitude, see Ortiz Treviño, "El Tercer Concilio Provincial Mexicano". 


\section{Bibliography}

\section{Printed Sources}

Recopilación de leyes de los reynos de Las Indias, (1), 5 vols., Madrid: Julián de Paredes, 1681, ed. Icaza Dufour, Francisco, México 1987.

Azpilcueta, Martín de, Manual de Confessores y Penitentes, Salamanca 1556: Andrea de Portonaris.

Burrus, Ernest, "Salazar's Report to the Third Mexican Council", in The Americas 17:1 (1960) 65-84.

Carrillo Cázares, Alberto, Manuscritos del Concilio Tercero Provincial Mexicano (1585). Edición, estudio introductorio, notas, versión paleográfica y traducción de textos latinos, vols. 1-3, 5 vols., México 20o6-20o9.

Colín, Francisco and Pablo Pastells, Labor evangélica. Ministerios apostólicos de los obreros de la Compañia de Iesus, fundación y progresos de su provincia en las Islas Filipinas, vol. 1, 3 vols., Barcelona 1900.

Covarrubias, Sebastián de, Tesoro de la lengua castellana o española, Madrid 1611: Luis Sánchez.

Gutiérrez, Lucio, "Domingo de Salazar's Report of 1582 on the Status of the Philippine Islands: A Manifesto for Freedom and Humanization (Part I)", in Philippiniana Sacra 21:62 (1986) 259-314.

Gutiérrez, Lucio, "Letter of Domingo de Salazar, OP, First Bishop of the Philippines to King Phillip II (1582)", in Philippiniana Sacra 22:68 (1988) 274-314.

Lorenzana, Francisco de, Concilios Provinciales Primero, y Segundo, Celebrados en la Muy Noble, y Muy Leal Ciudad de México, Presidiendo El Illmo. y Rmo. Señor D. Fr. Alonso de Montúfar, en los años de 1555, y1565, México 1768: Joseph Antonio de Hogal.

Martínez Ferrer, Luis, Decretos del Concilio Tercero Provincial Mexicano 1585. Edición histórico crítica y estudio preliminar por Luis Martínez Ferrer, 2 vols., Zamora 2009.

Murillo Velarde, Pedro, Cursus Iuris Canonici, Hispani, et Indice. In quo iuxta ordinem titulorum Decretalium non solum canonicae decissiones afferuntur, sed insuper additur, quod in nostro Hispaniae Regno, [...] lege, consuetudine, privilegio [...] admissum est, vol. 1, 2 vols., Madrid 1743: Manuel Fernández.

Salazar, "Tratado en que se determina lo que se ha de tener acerca de llevar tributos a los infieles de las Islas Filipinas", in Hanke, Lewis and Agustín Millares Carlo (eds.), Cuerpo de documentos del siglo XVI. Sobre los derechos de España en las Indias y las Filipinas, México 1943, 117-184.

Zorita, Alonso de, Historia de la Nueva España, vol. 1, Madrid $19 \circ 9$.

\section{Literature}

Díaz de la Guardia y López, Luis, "Granada y el derecho en el Concilio Tercero Mexicano (1585)", in Lira, Andrés, Alberto Carrillo Cázares and Claudia Ferreira 
Ascencio (eds.), Derecho, política y sociedad en Nueva España a la luz del Tercer Concilio Provincial Mexicano (1585), México 2013 147-177.

Fernández Rodríguez, Pedro, Los dominicos en el contexto de la primera evangelización de México (1526-1550), Salamanca 1994.

González Pola, Manuel, "Fundación de la Provincia de Nuestra Señora del Rosario", in Philippiniana Sacra 23:67 (1988) 121-153.

González Pola, Manuel, “Aportación de la Provincia de Santiago de México a la fundación de la Provincia de Nuestra Señora del Rosario de Filipinas desde la perspectiva del siglo XX", in Barrado Barquilla, José and Santiago Rodríguez (eds.), Los dominicos y el Nuevo Mundo. Siglos XIX-XX. Actas del $V^{\circ}$ Congreso Internacional de Querétaro, Qro. (México) 4-8 septiembre 1995, Salamanca 1997, 85-134.

Gutiérrez, Lucio, "Domingo de Salazar, O.P., Primer Obispo de Filipinas, 1512-1594. Estudio Crítico histórico sobre su Vida y su Obra", in Philippiniana Sacra 11:33 (1976), 449-496.

Gutiérrez, Lucio, "Domingo de Salazar, O.P., Primer Obispo de Filipinas (1512-1594). Trabajo Misional y Civilizador en Méjico y Florida (1553-1576)", in Philippiniana Sacra 12:36 (1977), 494-568.

Moutin, Osvaldo Rodolfo, Legislar en la América hispánica en la temprana edad moderna. Procesos y características de la producción de los Decretos del Tercer Concilio Provincial Mexicano (1585), Frankfurt am Main 2016.

Ortiz Treviño, Rigoberto Gerardo, "El Tercer Concilio Provincial Mexicano, o cómo los obispos evadieron al Real Patronato Indiano", in Anuario Mexicano de Historia del Derecho 15 (2003) 77-94.

Pita Moreda, María Teresa, Los predicadores novohispanos del siglo XVI, Salamanca 1992. Poole, Stafford, "Successors to Las Casas", in Revista de Historia de América 61/62 (1966), 89-114.

Poole, Stafford, “Opposition to the Third Mexican Council”, in The Americas 25:2 (1968), 111-159.

Poole, Stafford, Pedro Moya de Contreras. Reforma católica y poder real en la Nueva España, 1571-1591, trans. Cázares, Alberto Carrillo, 2 ed., México 2012.

Semboloni, Lara, "El Tercer Concilio Provincial Mexicano y el Virrey. Una interpretación", in Lira, Andrés, Alberto Carrillo Cázares and Claudia Ferreira Ascencio (eds.), Derecho, política y sociedad en Nueva España a la luz del Tercer Concilio Provincial Mexicano (1585), México 2013, 359-370. 